Article

\title{
Trace Elements and Sulfur Isotopes of Sulfides in the Zhangquanzhuang Gold Deposit, Hebei Province, China: Implications for Physicochemical Conditions and Mineral Deposition Mechanisms
}

\author{
Shimin Zhen ${ }^{1,2}$, Dazhao Wang ${ }^{3, *}$, Xiaofei Yu ${ }^{1, *}$, Qingfei Wang ${ }^{2}$, Yongsheng $\mathrm{Li}^{1}$, \\ Zhongjian Zha ${ }^{2,4}$ and Jiang Wang ${ }^{2}$ \\ 1 Center of Development and Research, China Geological Survey, Beijing 100037, China; \\ zhenshimin0001@163.com (S.Z.); cgsyongshengli@163.com (Y.L.) \\ 2 State Key Laboratory of Geological Processes and Mineral Resources, China University of Geosciences, \\ Beijing 100083, China; wqf@cugb.edu.cn (Q.W.); zhazhongjina0815@163.com (Z.Z.); \\ wangjiang_work@163.com (J.W.) \\ 3 State Key Laboratory of Nuclear Resource and Environment, East China University of Technology, \\ Nanchang 330013, China \\ 4 Institute of Geological Surveying and Mapping Technology of Anhui Province, Hefei 230022, China \\ * Correspondence: wangdazhao@ecut.edu.cn (D.W.); xfyu@jlu.edu.cn (X.Y.)
}

Received: 12 November 2020; Accepted: 2 December 2020; Published: 6 December 2020

\begin{abstract}
The Zhangquanzhuang gold deposit is a special deposit in the Zhangjiakou district, on the northern margin of the North China Craton. It is characterized by the enrichment of sulfides, the scarcity of tellurides and zero to positive sulfur isotope compositions compared with the famous Dongping and Xiaoyingpan Te-Au-Ag deposit types of the same district. In this paper, we use the in-situ LA-(MC)-ICP-MS and bulk trace element concentrations of pyrite, and in-situ sulfur isotope compositions of sulfides, to study physicochemical conditions and mechanisms of mineral deposition in the Zhangquanzhuang deposit. Pyrite from stage I (PyI) contains high Te contents, pyrite from stage II (PyII) has the highest Co and Ni contents, and pyrite from stage III (PyIII) contains high Cr, $\mathrm{Zn}, \mathrm{Pb}, \mathrm{Ag}, \mathrm{Cu}, \mathrm{Sb}, \mathrm{Bi}$ and $\mathrm{Au}$ contents. The calculated in-situ $\delta^{34} \mathrm{~S}_{\mathrm{H} 2 \mathrm{~S}}$ values range from $0.9 \%$ o to $6.1 \%$, and the values for stages I and II are higher than those for stage III. The mineral assemblages and trace element contents in pyrite show that large amounts of metals precipitated during stage III, in which the $\mathrm{pH}$ and $\log f \mathrm{O}_{2}$ were constrained within the range of 4.1 to 5.2 and -36.9 to -32.1 , respectively. Sulfidation and boiling derived from decreasing pressure may be the main mechanisms leading to mineral deposition in stage III. The Zhangquanzhuang gold deposit was formed in a mineral system that was different from the one that formed the Dongping and Xiaoyingpan Te-Au-Ag deposits, and should thus be called the "Zhangquanzhuang-type" deposit and considered a third gold deposit type in the Zhangjiakou ore field.
\end{abstract}

Keywords: trace elements; sulfur isotope; LA-(MC)-ICP-MS; pyrite; Zhangquanzhuang gold deposit

\section{Introduction}

The Zhangjiakou ore field in Hebei Province is located on the northern margin of the North China Craton. It is one of the most important gold producing areas in China. More than 25 gold deposits have been discovered in this ore field [1,2]. With respect to the host rocks, the deposits in the Zhangjiakou ore field can be divided into the "Dongping-type" and the "Xiaoyingpan-type" gold deposits, where the former is commonly hosted in the altered Shuiquangou syenitic complex [3-5], while the latter is 
hosted in metamorphic rocks of the Archean Sanggan Group [6]. Most of these deposits exhibit several common features, such as enrichment in tellurides, low sulfide contents, intense K-feldspathization and relatively high gold fineness $[1,5,7,8]$.

The Zhangquanzhuang gold deposit is a medium-sized gold deposit located south of the Shangyi-Chongli-Chicheng fault. It has rare tellurides and high sulfide volumes, which make it different from the other two main Te-Au-Ag deposits of the district. Some studies have been performed on the Zhangquanzhuang gold deposit; however, most of them were published in Chinese in the 1990s [9-13]. Yin and Shi $(1994 a, b)[9,13]$ focused on the chemical and typomorphic characteristics of quartz and pyrite, and concluded that the Zhangquanzhuang gold deposit is a metamorphic mesothermal-hypothermal type of deposit. Li and Shi (1999) [12] established an elemental geochemical model of the deposit and predicted the existence of deeper orebodies. Shui (2000) [11] studied the geological-tectonic features and mineralization regularities of the Zhangquanzhuang deposit, and evaluated its ore-prospecting potential. Recently, Zhen et al. (2020) [14] published mineral paragenesis and multiple isotope $(\mathrm{S}, \mathrm{Pb}, \mathrm{H}, \mathrm{O}, \mathrm{He}$ and $\mathrm{Ar})$ data of the Zhangquanzhuang deposit, and concluded that it formed as a result of the reactivation of mantle lithosphere previously metasomatized by fertile subduction-related fluids. Issues related to elemental compositions and precipitation mechanisms of sulfides remain poorly constrained, which precludes the discussion of relationships between Zhangquanzhuang and other Te-Au-Ag deposits and gold mineralization events in the Zhangjiakou district.

In this paper, we evaluate the in-situ and bulk trace element concentrations of pyrite and in-situ sulfur isotope compositions of sulfides to determine the origin of metals and composition of ore-forming fluids, and discuss the mechanisms of ore deposition in the Zhangquanzhuang gold deposit. We also discuss the differences between the gold mineralization types in the Zhangjiakou ore field.

\section{Geological Setting}

The Zhangquanzhuang gold deposit is located on the northern margin of the North China Craton (Figure 1a). The Shangyi-Chongli-Chicheng fault is a mantle-penetrating fault [15], and it controlled the emplacement of igneous rocks and the distribution of gold mineralization in the region. Multiple stages of tectonic-magmatic events have developed in this region, including (1) Neoarchean crustal growth and stabilization, (2) Paleoproterozoic rifting-subduction-accretion-collision, (3) late Paleoproterozoic-Neoproterozoic multistage stage rifting, (4) Paleozoic subduction of the Paleo-Asian Ocean, and (5) Mesozoic lithospheric thinning and decratonization [16]. The stratigraphic units exposed in the region are the Archean Sanggan Group, the Proterozoic Hongqiyingzi Groups, and the Changcheng and Jixian systems, the Cretaceous Zhangjiakou Formation and Quaternary sediments (Figure 1b). The Archean Sanggan metamorphic complex is exposed mostly to the south of the Shangyi-Chongli-Chicheng fault, and is dominated by amphibolites, granulites and leptites generated from a series of mafic to felsic volcaniclastic rocks and clastic sediments. The Paleoproterozoic Hongqiyingzi Group is exposed to the north of the fault with the dominant lithologies of marble, quartzite, amphibolite, and gneiss. The Mesoproterozoic Changcheng and Jixian Systems, consisting of sandstone and dolomite, occur in the southeastern corner of this area. The Cretaceous Zhangjiakou Formation of volcanic-sedimentary rocks consists of rhyolite, rhyodacite, trachyte and pyroclastic flows, which are widely distributed in this region (Figure 1b).

The igneous rocks in the region include Neoarchean to Paleoproterozoic granodiorite [17], the Mesoproterozoic Wenquan rapakivi granite [18], the Devonian Shuiquangou syenite complex ( 400 Ma) [19], the Triassic Xiangshuigou, Guzuizi and Honghualiang granites ( 230 Ma) [20,21], the Cretaceous Shangshuiquan alkali granite and Zhuanzhilian diorite ( 140 Ma) [20,22], and the Cretaceous Zhangjiakou Formation volcanic rocks ( 130 Ma) [17]. The Devonian syenite complex was derived from the collision between the North China Craton and the Paleo-Asian Ocean plate [19]. 
The Triassic granites were formed by partial melting of ancient lower crust [21] and the Cretaceous igneous rocks were related to the subduction of the Pacific plate under the Eurasian continent [20].

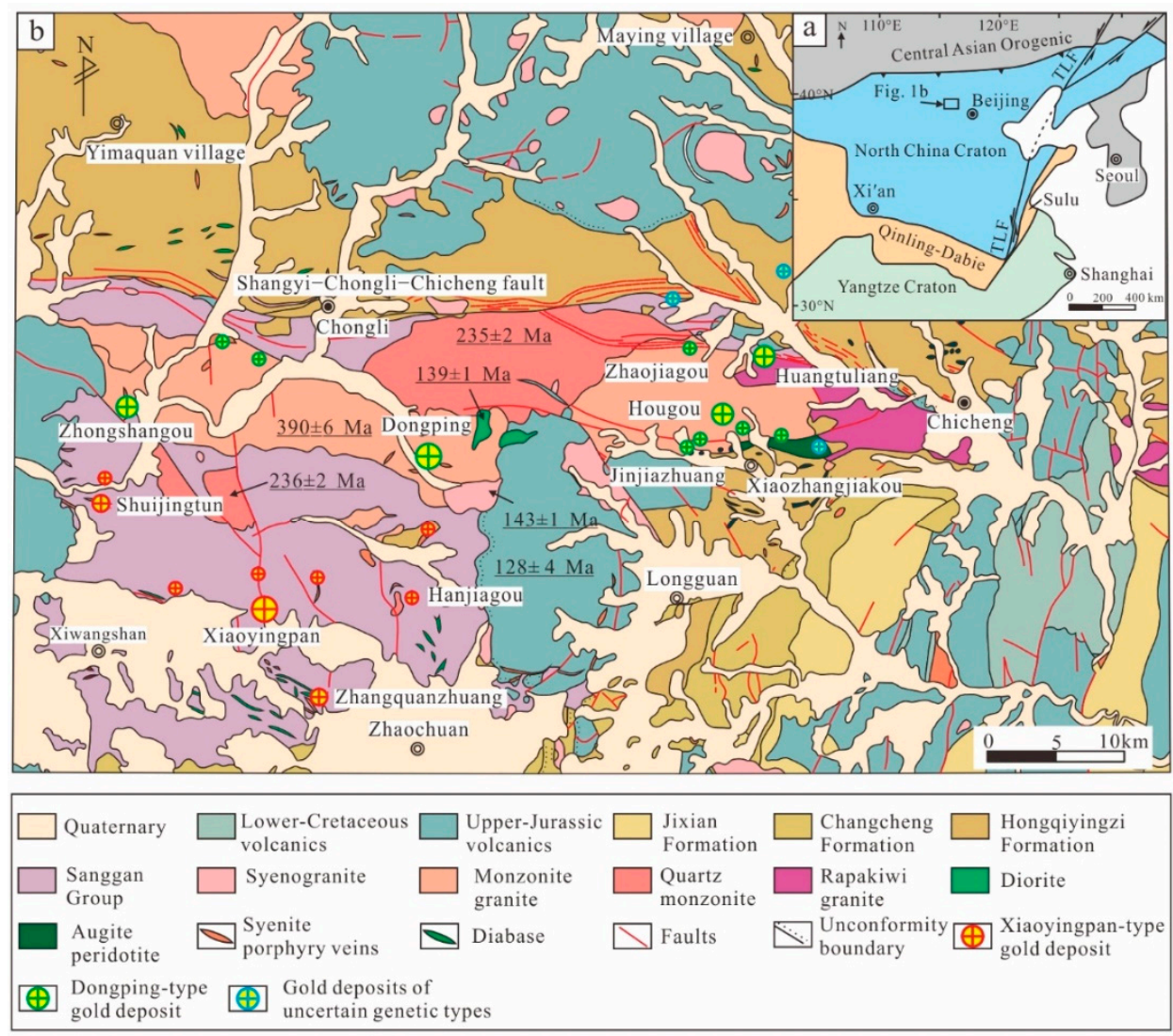

Figure 1. Sketch maps of (a) the North China Craton and (b) the geology of Northern Hebei Province (modified after Wang et al. (2019) [5]) showing the locations of the gold deposits.

\section{Ore Deposit Geology}

The Zhangquanzhuang gold deposit is located south of the Shangyi-Chongli-Chicheng fault (Figure 1b), approximately $20 \mathrm{~km}$ south of the Dongping gold deposit and $7 \mathrm{~km}$ southeast of the Xiaoyingpan gold deposit. It is hosted in metamorphic rocks of the Archean Sanggan Group (Figure 2). Igneous rocks in the ore field are mainly diabase and diorite dykes (Figure 2). Most of these dykes trend northwest-southeast with widths of $0.5-2 \mathrm{~m}$.

NW-SE and N-S striking faults are the main ore-hosting structures in the Zhangquanzhuang gold deposit (Figure 2). More than 50 auriferous quartz veins have been identified and the longest quartz vein is more than $2500 \mathrm{~m}$ long (Figure 2). Individual orebodies occur as lenses or veins with an average thickness of $1.2 \mathrm{~m}$, attitudes of 50-100 $\angle 60-80$ and Au grades of 1.17 to $3.63 \mathrm{~g} / \mathrm{t}$ (Figure 3). Most of the mineralized veins are hosted in the Archean Sanggan plagioclase-amphibole gneiss, granulite and migmatite [9]. The ore styles in the deposit are mainly auriferous quartz veins and disseminated ores. Minerals include pyrite, galena, sphalerite, chalcopyrite, tetrahedrite, native gold, electrum, quartz, K-feldspar, fluorite, calcite and sericite [14]. Silicification, sericitization and chloritization are widely developed. Zhen et al. (2020) [14] subdivided mineralization into four stages, namely, the K-feldspar-quartz stage (stage I), the pyrite-quartz stage (stage II), the polymetallic sulfide-quartz stage (stage III), and the calcite-quartz stage (stage IV). 


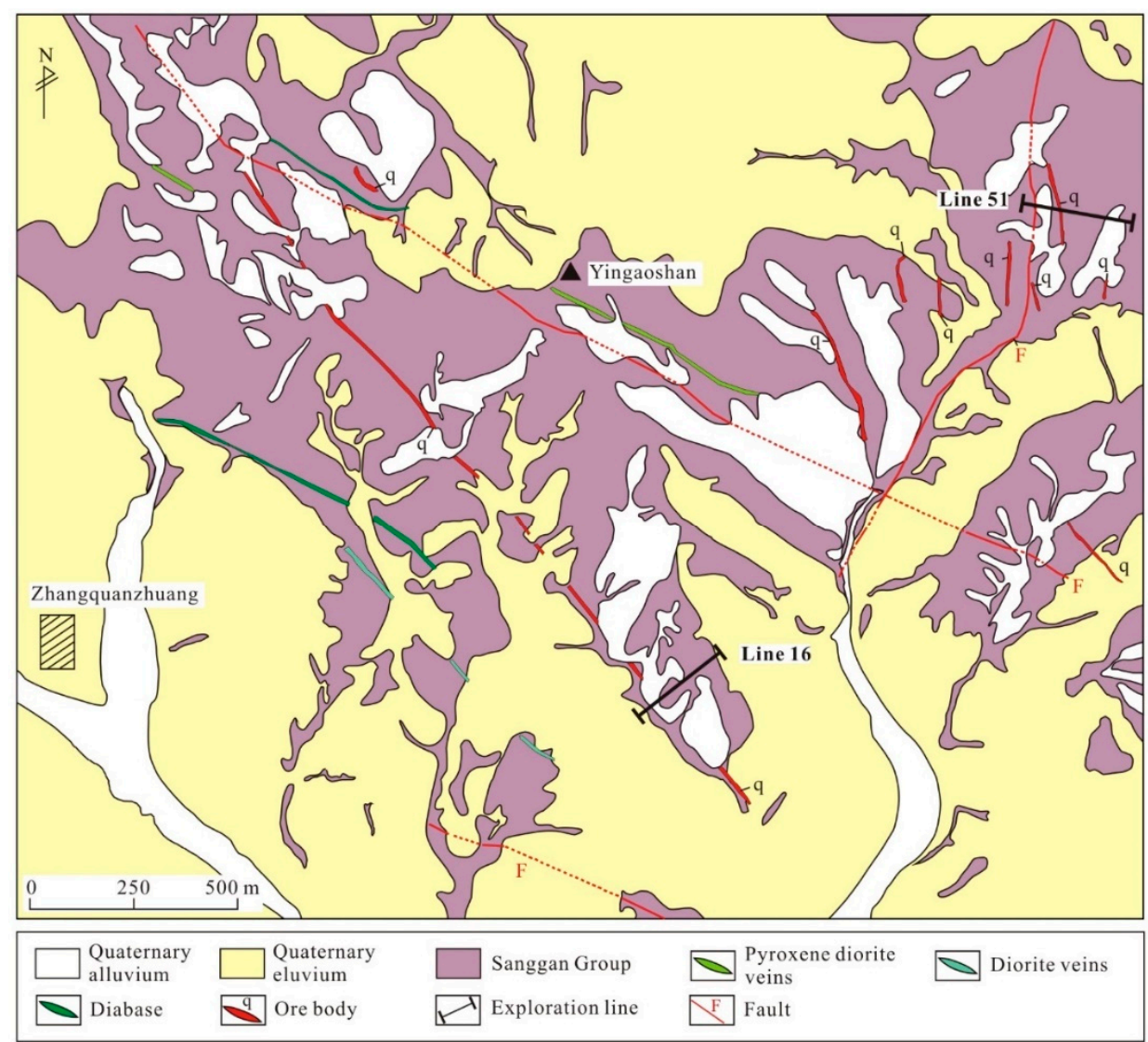

Figure 2. Geological map of the Zhangquanzhuang gold deposit (modified after Shengde Mining in Xuanhua, 2015, unpublished mining report).
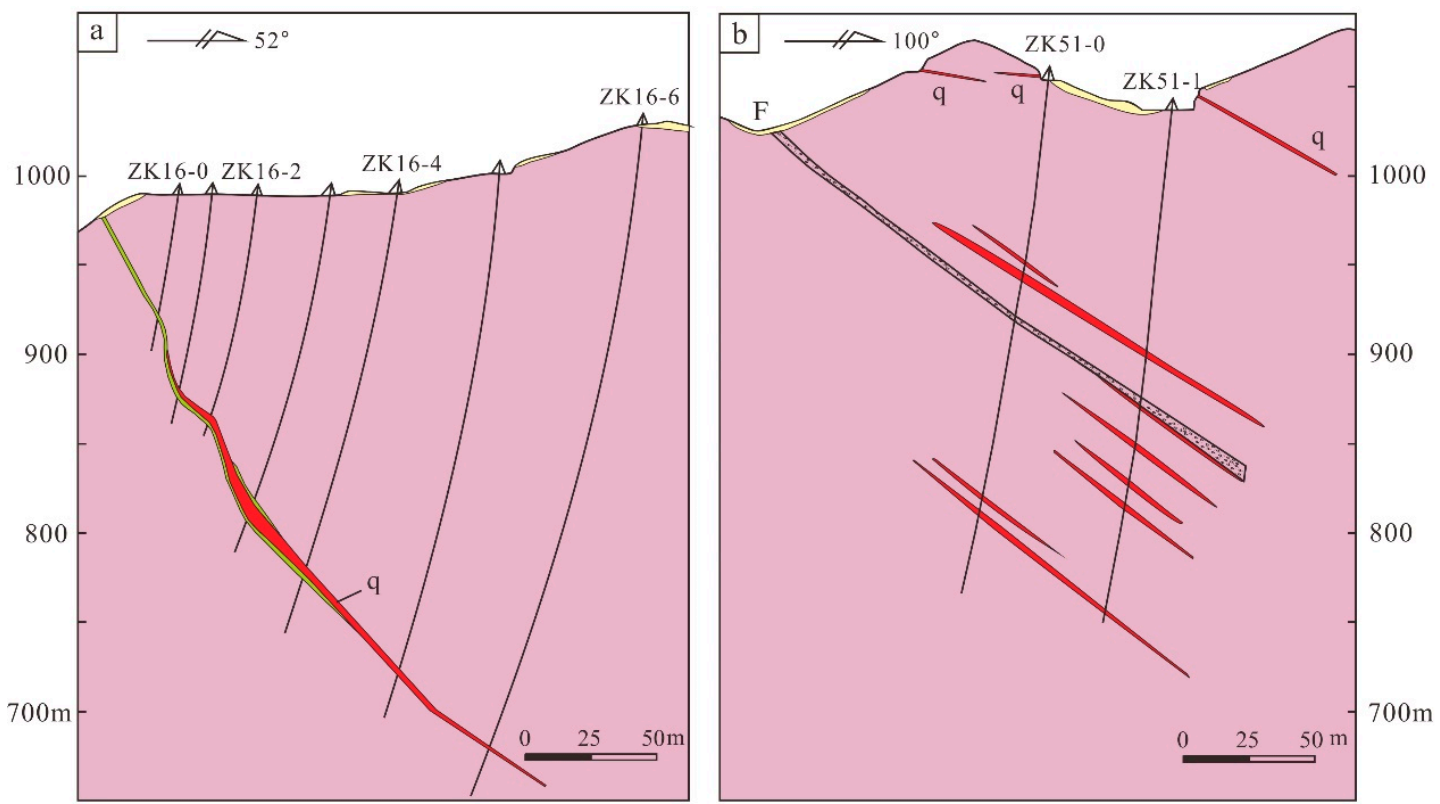

Quaternary

Pyroxene diorite vein 9 Ore body Fault

4 Drill hole

Figure 3. Geological cross sections of (a) exploration line 16 and (b) exploration line 51 (modified after Shengde Mining in Xuanhua, 2015, unpublished mining report). 


\section{Sample Description and Analytical Methods}

Pyrite from different mineralization stages was selected for in-situ trace element and sulfur isotope analysis. Pyrite from stage I (PyI) is euhedral, disseminated and fine grained (Figure 4a-c, Table 1). Pyrite from stage II (PyII) is euhedral and coarse-grained with scarce mineral inclusions (Figure $4 \mathrm{~d}-\mathrm{h}$, Table 1). Pyrite from stage III (PyIII) occurs as veins, which coexists with other sulfides such as galena, chalcopyrite and/or sphalerite (Figure 4i-1, Table 1), and many micro- to nano-scale mineral inclusions (including galena, chalcopyrite, native gold and other species) developed in PyIII.

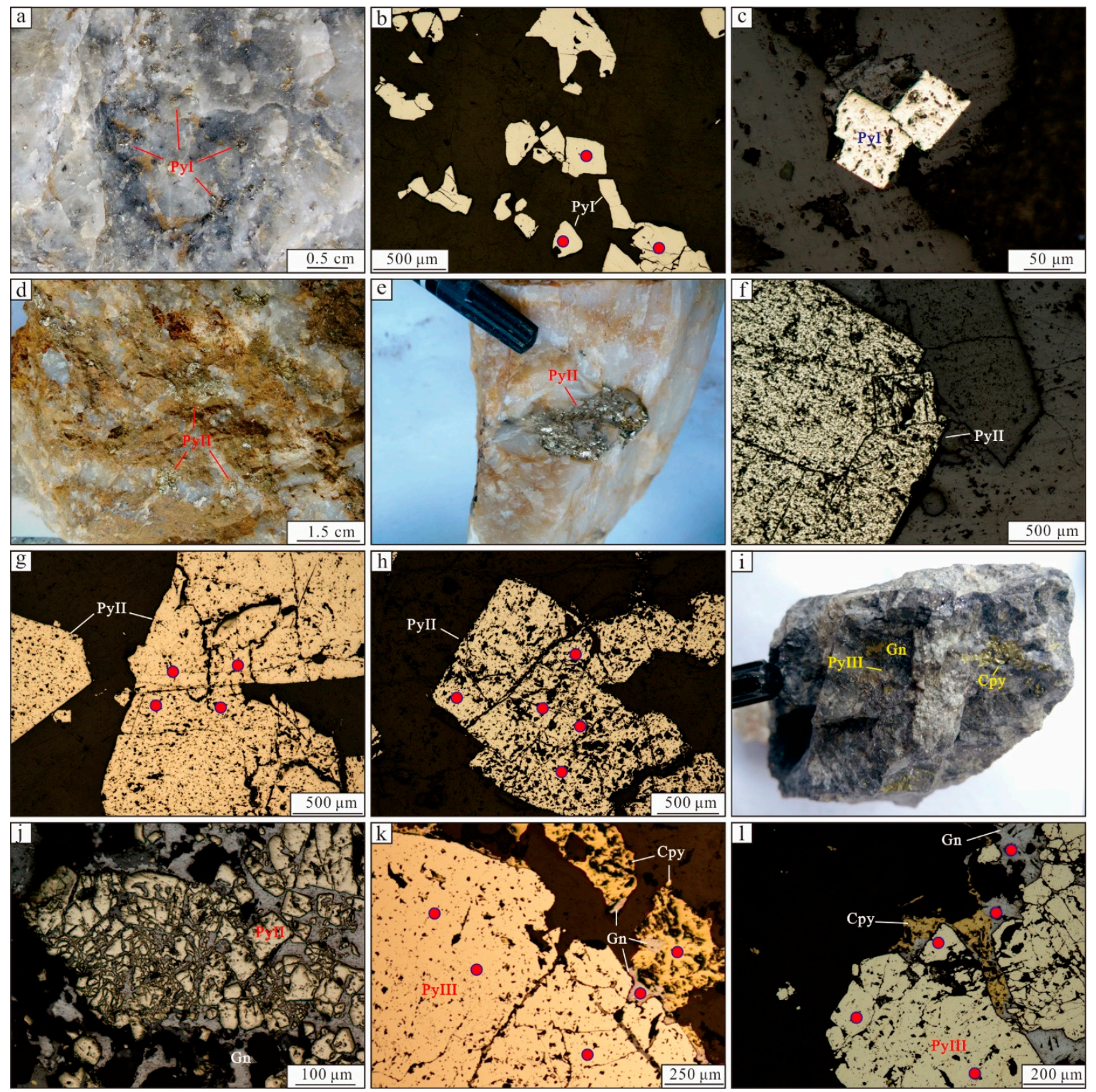

Figure 4. Sample and reflected light microscope photographs of pyrite from different stages. (a) Sample and $(\mathbf{b}, \mathbf{c})$ reflected light microscope photographs of pyrite from stage I (PyI), showing euhedral, disseminated and fine-grained occurrences; (d,e) sample and (f,h) reflected light microscope photographs of pyrite from stage II (PyII), showing euhedral and coarse-grained habits with scarce rare mineral inclusions; (i) sample and $(\mathbf{j}, \mathbf{l})$ reflected light microscope photographs of pyrite from stage III (PyIII), coexisting with galena, chalcopyrite and/or sphalerite, and hosting many micro- to nano-scale mineral inclusions; (j) shows galena formed in stage III, and PyII is altered and crushed. Abbreviations: Cpy = chalcopyrite, $\mathrm{Gn}=$ galena, $\mathrm{PyI}=$ pyrite in stage $\mathrm{I}, \mathrm{PyII}=$ pyrite in stage $\mathrm{II}$ and PyIII = pyrite in stage III. 
Table 1. Characteristics of pyrite from stages I, II and III.

\begin{tabular}{ccc}
\hline Samples & Characteristics & Metal Minerals \\
\hline pyrite from stage I & euhedral, disseminated, fine grained, & unaltered \\
pyrite from stage II & $\begin{array}{c}\text { euhedral, coarse, altered by sulfides } \\
\text { formed in stage III, sometimes } \\
\text { fragmented, } \\
\text { pyrite from stage III }\end{array}$ & $\begin{array}{c}\text { scarce, include little } \\
\text { chalcopyrite } \\
\text { veins, coarse }\end{array}$ \\
\hline
\end{tabular}

\subsection{In-Situ Trace Elements Analysis}

In-situ trace elements of pyrite were analyzed by LA-ICP-MS at the National Research Center for Geoanalysis, Chinese Academy of Geological Sciences. Laser sampling was performed using a COMPexPro 102 ArF excimer laser. An Agilent 7700e ICP-MS instrument was used to acquire ion signal intensities. Helium was applied as a carrier gas. Argon was used as the make-up gas and mixed with the carrier gas via a T-connector before entering the ICP. The spot size and frequency of the laser were set to $40 \mu \mathrm{m}$ and $5 \mathrm{~Hz}$, respectively. The standard sample NIST SRM 610 was used to correct the time-dependent drift of sensitivity and mass discrimination [23]. Time-drift correction was conducted by the software ICPMS-DataCal, using ${ }^{57} \mathrm{Fe}$ as the internal standard. [23].

\subsection{In-Situ Sulfur Isotope Analysis}

In-situ sulfur isotope analyses were carried out using LA-MC-ICP-MS at the State Key Laboratory of Continental Dynamics, Northwest University, China, following the methods of Chen et al. (2017) [24]. The instruments included an NWR UP Femto femtosecond laser coupled with the Nu Plasma 1700 MC-ICP-MS. The energy fluence of the laser was approximately $3 \mathrm{~J} / \mathrm{cm}^{2}$. For single spot analysis, the diameter was $15 \mu \mathrm{m}$ with a laser repletion rate of $10 \mathrm{~Hz}$. An in-house pyrite standard named PSPT- 3 was used to calibrate the mass bias for $S$ isotopes. The results of $S$ isotope data are expressed against the CDT standard.

\subsection{Bulk Trace Elements of Pyrite}

Five samples of stages II and III pyrite were analyzed for bulk chemical compositions. Pyrite was crushed into grains with sizes of $0.1-0.5 \mathrm{~mm}$ and handpicked under a binocular microscope with a purity of $>99 \%$. Trace element concentrations were measured on an HR-ICP-MS apparatus in the analytical laboratory center of the Beijing Research Institute of Uranium Geology, following the methods of Li et al. (1995) [25].

\section{Results}

\subsection{In-Situ Chemical Composition of Pyrite}

A total of 34 elements were analyzed to investigate the pyrite chemical compositions (Table S1), of which $\mathrm{Ga}, \mathrm{Rb}, \mathrm{Y}, \mathrm{Nb}, \mathrm{In}, \mathrm{W}, \mathrm{Re}, \mathrm{Hg}$, $\mathrm{Ta}$, $\mathrm{Cs}$ and $\mathrm{Tl}$ were below the detection limits in most spots. Manganese, $\mathrm{Co}, \mathrm{Ni}, \mathrm{Cu}, \mathrm{Zn}, \mathrm{Ge}, \mathrm{As}, \mathrm{Mo}, \mathrm{Ag}$ and $\mathrm{Pb}$ were detected in most analyses, with concentrations spanning three to four orders of magnitude (Figure 5). Cr, Se and Sn were detected in a half of the analyses, $\mathrm{Sb}$ and Bi were detected mostly in PyIII analyses, and Au was only detected in three spots from PyIII.

PyI (pyrite in stage I) contains relatively higher Te (up to $1.39 \mathrm{ppm}$ ), and lower $\mathrm{Zn}$ and As (Figure 5). PyII (pyrite in stage II) has the highest Co and Ni contents, with maximum values of 1108.17 and 666.88 ppm, respectively. Other trace element contents of PyII have no obvious difference from those form that of PyI. PyIII (pyrite in stage III) contains high concentrations of $\mathrm{Cr}, \mathrm{Zn}, \mathrm{Pb}, \mathrm{Ag}$ and $\mathrm{Cu}$, with values 
reaching 106.01, 2282.27, 510.92, 145.41 and 329.73 ppm, respectively. Antimony, Bi and Au in PyIII have concentrations of 0.14-11.43, 0.14-22.27 and 0.69-1.42 ppm, respectively.

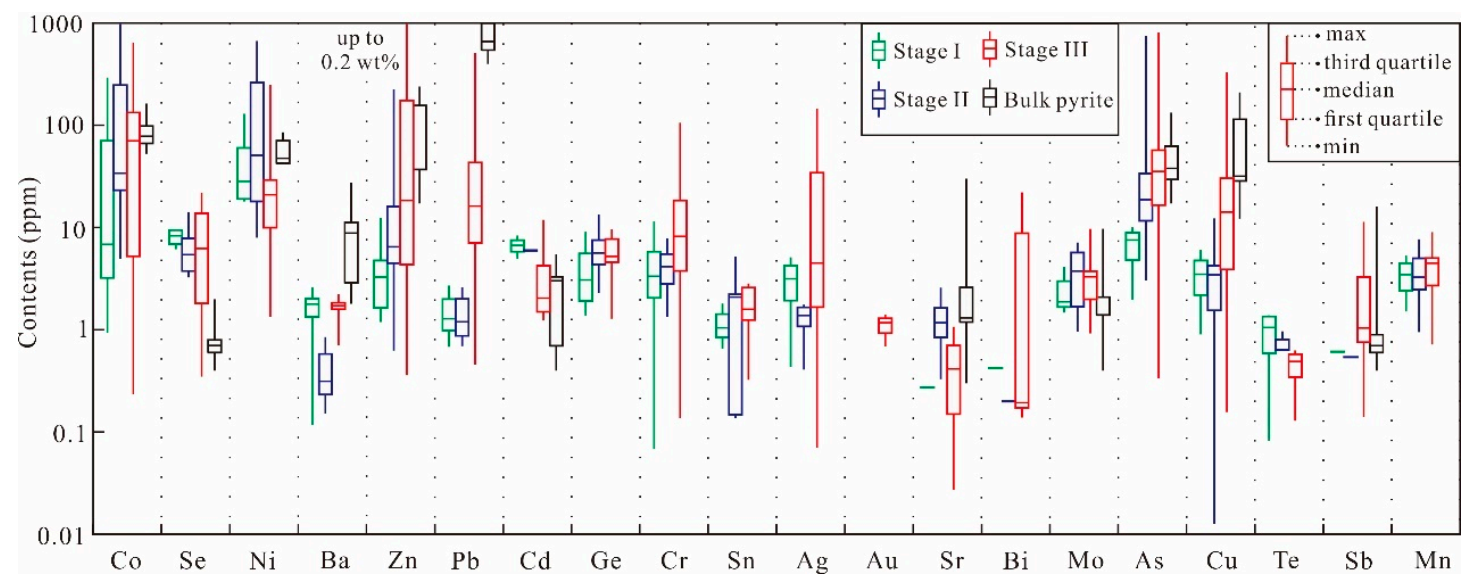

Figure 5. Concentration plot for trace elements in pyrite from the Zhangquanzhuang gold deposit.

\subsection{In-Situ Sulfur Isotope Compositions}

A total of 49 spots were analyzed in-situ for sulfur isotope compositions including seven spots of PyI, 16 spots of PyII, 14 spots of PyIII, six spots of GnIII (galena from stage III) and six spots of CpyIII (chalcopyrite from stage III), and the results are listed in Table S2. The range of $\delta^{34} \mathrm{~S}$ values varies from 4.9 to $6.3 \%$, 4.7 to $7.3 \%$ o and 2.6 to $4.9 \%$ o for PyI, PyII and PyIII, respectively. GnIII yielded $\delta^{34} \mathrm{~S}$ values between 0.7 and 3.9\%o, and CpyIII yielded values between 1.2 and 3.7\%o. Based on the homogenization temperatures of fluid inclusions ( $300{ }^{\circ} \mathrm{C}$ for stages I to III) [8] and the sulfides $-\mathrm{H}_{2} \mathrm{~S}$ equations of Ohmoto (1972) [26], the $\delta^{34} \mathrm{~S}_{\mathrm{H} 2 \mathrm{~S}}$ values are calculated range from 0.9 to $6.1 \%$. The ore-forming fluids of stages I and II have the same $\delta^{34} \mathrm{~S}_{\mathrm{H} 2 \mathrm{~S}}$ values, and are slightly but obviously higher than those of stage III (Figure 6).

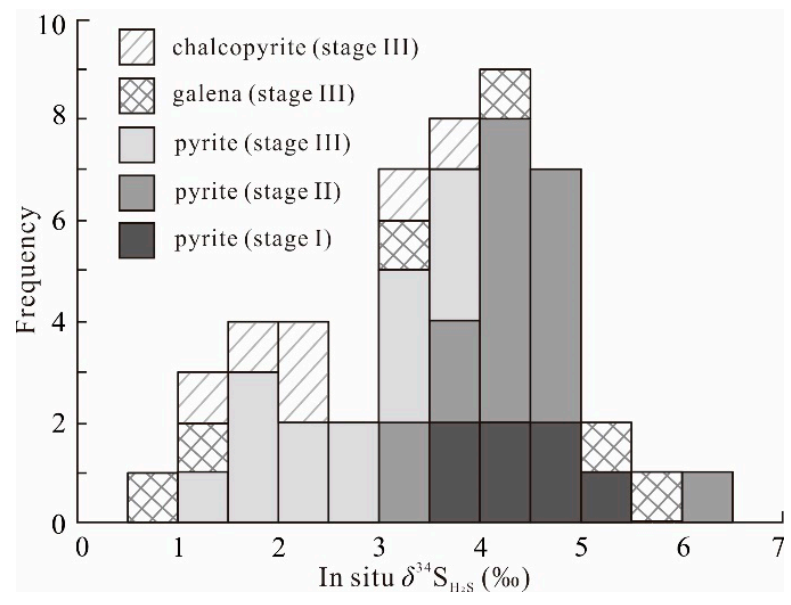

Figure 6. Histograms of in-situ sulfur isotope composition of the Zhangquanzhuang gold deposit.

\subsection{Bulk Chemical Composition of Pyrite}

The chemical compositions of five samples of pyrite were analyzed (Table S3). Some elements in some samples are below the detection limits. Cobalt contents range from 52.6 to 163.8 ppm and $\mathrm{Ni}$ contents range from 42.6 to $86.1 \mathrm{ppm}$ (Figure 5). Copper, $\mathrm{Zn}, \mathrm{Pb}$ and As contents are variable, with values reaching to 211.1, 240.7, 1758.9 and $133.7 \mathrm{ppm}$, respectively. Gallium, Se, Rb, Sn, Sb and Zr contents are below 1 ppm in most samples. Strontium, Mo, Cd, Ba and W contents are approximately at or below $10 \mathrm{ppm}$. 


\section{Discussion}

\subsection{Factor Analysis of Trace Element Compositions}

Principal component analysis identified 6 factors from the in-situ trace element data of pyrite (Table 2). Factor 1 is dominated by $\mathrm{Cr}, \mathrm{Ag}, \mathrm{Sb}, \mathrm{Ba}, \mathrm{Au}, \mathrm{Pb}, \mathrm{Bi}$; Factor 2 is mainly represented by $\mathrm{Mn}, \mathrm{Co}$, $\mathrm{Ni}, \mathrm{Zn}, \mathrm{Sr} ; \mathrm{Zn}$ and Cd contribute mainly to Factor 3; Cu, Zn, As, Se, Cr have positive loadings on Factor 4; Factor 5 contains positive $\mathrm{Co}, \mathrm{Ni}$, Se, Te, $\mathrm{Pb}, \mathrm{Bi}$ and $\mathrm{Sr}$; Factor 6 is mainly contributed by $\mathrm{Cr}$ and $\mathrm{Mo}$.

Different elements have different mechanisms to enter pyrite. Cobalt, Se and Ni mainly enter the lattice of pyrite $[27,28]$. Lead, $\mathrm{Zn}, \mathrm{Cd}, \mathrm{Ge}, \mathrm{Sr}, \mathrm{Bi}$ and $\mathrm{Sn}$ more likely exist in pyrite as micro mineral inclusions (such as galena, sphalerite and Bi-bearing minerals) [29,30]. Molybdenum, As and Sb could associate with pyrite both as lattice substitutions and inclusions; Mn, V and U are probably adsorbed onto the mineral's surfaces [31]. Based on these mechanisms of element association and rotation matrix of principal component analysis, Factor 1 represents the elements in micro-inclusions of sulfosalts or galena, Factor 2 can be regarded as a lattice-bound group of elements, Factor 3 refers to the elements in micro-inclusions of sphalerite, Factor 4 refers to the elements in chalcopyrite, Factor 5 may relate to the elements adsorbed onto Fe-sulfide surfaces or lattice-bound elements [31], and Factor 6 may reflect the existence of molybdenite micro-inclusions.

\subsection{Controls on Trace Element Distribution in Pyrite}

Trace elements in pyrite can exist in the lattice or as mineral inclusions and nanoparticles. Their concentrations are affected by the existence of mineral inclusions, and the compositions and physicochemical conditions of mineralizing fluids [32].

Generally, Co, Se and Ni mainly enter into the lattice of pyrite, showing smooth and similar spectra (Figure 7a) [33]. Copper, Zn, As, Te, Ag and Au can enter pyrite both as lattice substitutions and inclusions, showing smooth or heterogeneous spectra (Figure $7 b-d)[27,28,33]$. Lead does not prefer to enter the pyrite crystal lattice because of its large ionic size; in contrast, it more likely exists in pyrite as galena inclusions (Figure 7d). Lead, Ag and Sb have similar behaviors [30] and show covariation patterns (Figure 8a,b), and they are more concentrated in PyIII, indicating higher proportions of galena inclusions in stage III of mineralization [34]. Bismuth prefers to incorporate into galena or chalcopyrite inclusions [27,35], which could be the reason that $\mathrm{Bi}$ is rare in PyI and PyII but could be detected in PyIII analyses. Cd and Ge prefer to incorporate into sphalerite, while their contents in pyrite are low and show scattered distributions with Zn (Figure 8c,d), indicating that sphalerite inclusions are not the only source of $\mathrm{Zn}$ in pyrite, and that a certain percentage of $\mathrm{Zn}$ may exist in the lattice of pyrite [29].

Cobalt and Ni contents of the in-situ data vary and display a positive correlation (Figure 8e) with $\mathrm{Co} / \mathrm{Ni}$ ratios ranging from 0.04 to 22.9. This characteristic may be related to the existence of Co- or Ni-bearing inclusions. However, $\mathrm{Co}$ and Ni contents of the bulk pyrite analyses are uniform and yield median values compared with the in-situ data (Figures 5 and 8e), which preclude the influence of Coor Ni-bearing inclusions. This conclusion is also shown in the smooth ablation profiles for Co and $\mathrm{Ni}$ (Figure 7). One possible explanation is that $\mathrm{Co}$ and $\mathrm{Ni}$ are unevenly distributed in the pyrite crystal lattice, implying that the in-situ analysis data must be treated carefully. Cobalt and Ni contents in pyrite are significantly influenced by fluid temperature, where Co prefers to enter the pyrite crystal lattice at high temperatures, while Ni prefers to enter the pyrite crystal lattice at low temperatures [36,37]. As a result, Co:Ni ratios have been widely used to determine the origin of pyrite [38,39]. Most of the in-situ and bulk analyses have Co:Ni ratios of approximately 1 or higher (Figure 8e), indicating a hydrothermal/magmatic origin $[39,40]$. 
Table 2. Results of factor analysis of the pyrite LA-ICP-MS data.

\begin{tabular}{|c|c|c|c|c|c|c|}
\hline \multicolumn{7}{|c|}{ Principal Component Analysis } \\
\hline Element & Factor 1 & Factor 2 & Factor 3 & Factor 4 & Factor 5 & Factor 6 \\
\hline Eigenvalue & 4.846 & 2.942 & 1.957 & 1.877 & 1.501 & 1.402 \\
\hline Variance \% & 24.231 & 14.709 & 9.784 & 9.383 & 7.504 & 7.009 \\
\hline $\begin{array}{c}\text { Cumulative } \\
\%\end{array}$ & 24.231 & 38.941 & 48.725 & 58.108 & 65.612 & 72.621 \\
\hline $\mathrm{Cr}$ & 0.670 & 0.062 & 0.014 & -0.050 & -0.162 & 0.544 \\
\hline Mn & -0.088 & 0.476 & -0.274 & -0.541 & -0.300 & -0.012 \\
\hline $\mathrm{Co}$ & -0.219 & 0.848 & -0.029 & 0.122 & 0.289 & 0.081 \\
\hline $\mathrm{Ni}$ & -0.221 & 0.601 & 0.233 & -0.226 & 0.424 & 0.213 \\
\hline $\mathrm{Cu}$ & 0.121 & 0.502 & -0.296 & 0.638 & -0.311 & -0.017 \\
\hline $\mathrm{Zn}$ & 0.103 & -0.023 & 0.818 & 0.351 & -0.171 & -0.193 \\
\hline $\mathrm{Ge}$ & 0.151 & -0.394 & 0.063 & -0.394 & -0.430 & 0.029 \\
\hline As & -0.069 & 0.253 & -0.334 & 0.690 & -0.230 & 0.185 \\
\hline Se & -0.034 & -0.387 & -0.100 & 0.237 & 0.677 & 0.237 \\
\hline Mo & 0.238 & -0.065 & 0.287 & -0.054 & -0.170 & 0.836 \\
\hline $\mathrm{Ag}$ & 0.791 & 0.016 & -0.015 & -0.095 & -0.132 & -0.172 \\
\hline $\mathrm{Cd}$ & -0.211 & 0.153 & 0.805 & 0.165 & -0.103 & -0.182 \\
\hline Sn & -0.256 & 0.764 & 0.127 & -0.172 & -0.159 & -0.052 \\
\hline $\mathrm{Sb}$ & 0.927 & 0.114 & 0.061 & 0.037 & 0.046 & 0.133 \\
\hline $\mathrm{Te}$ & -0.268 & -0.448 & -0.175 & 0.013 & 0.119 & -0.089 \\
\hline $\mathrm{Ba}$ & 0.488 & 0.067 & -0.367 & 0.151 & -0.060 & -0.228 \\
\hline $\mathrm{Au}$ & 0.864 & 0.043 & -0.014 & -0.097 & -0.057 & -0.175 \\
\hline $\mathrm{Pb}$ & 0.850 & 0.097 & 0.105 & 0.073 & 0.285 & -0.160 \\
\hline $\mathrm{Bi}$ & 0.871 & 0.104 & 0.101 & 0.061 & 0.263 & -0.117 \\
\hline $\mathrm{Sr}$ & 0.218 & 0.399 & -0.076 & -0.430 & 0.210 & -0.111 \\
\hline \multicolumn{7}{|c|}{ Rotation of the Principal Component Analysis Matrix } \\
\hline Element & Factor 1 & Factor 2 & Factor 3 & Factor 4 & Factor 5 & Factor 6 \\
\hline $\mathrm{Cr}$ & 0.512 & -0.058 & -0.122 & 0.082 & 0.058 & 0.699 \\
\hline $\mathrm{Mn}$ & -0.064 & 0.222 & -0.355 & -0.093 & 0.710 & 0.007 \\
\hline Co & -0.080 & 0.869 & -0.012 & 0.292 & 0.145 & -0.066 \\
\hline $\mathrm{Ni}$ & -0.125 & 0.817 & 0.046 & -0.196 & 0.060 & 0.115 \\
\hline $\mathrm{Cu}$ & 0.148 & 0.137 & 0.016 & 0.886 & 0.177 & -0.045 \\
\hline $\mathrm{Zn}$ & 0.125 & -0.077 & 0.919 & 0.028 & -0.036 & 0.040 \\
\hline $\mathrm{Ge}$ & 0.030 & -0.541 & -0.030 & -0.325 & 0.286 & 0.204 \\
\hline As & -0.100 & 0.033 & -0.058 & 0.849 & -0.063 & 0.070 \\
\hline Se & -0.047 & 0.080 & -0.187 & -0.097 & -0.823 & 0.031 \\
\hline Mo & 0.019 & -0.023 & 0.074 & -0.039 & -0.052 & 0.929 \\
\hline $\mathrm{Ag}$ & 0.780 & -0.200 & -0.018 & -0.026 & 0.169 & 0.061 \\
\hline $\mathrm{Cd}$ & -0.149 & 0.158 & 0.851 & -0.088 & 0.090 & -0.030 \\
\hline Sn & -0.155 & 0.576 & 0.131 & 0.105 & 0.580 & -0.043 \\
\hline $\mathrm{Sb}$ & 0.882 & 0.002 & -0.004 & 0.055 & -0.030 & 0.341 \\
\hline $\mathrm{Te}$ & -0.282 & -0.285 & -0.158 & -0.121 & -0.288 & -0.204 \\
\hline $\mathrm{Ba}$ & 0.517 & -0.139 & -0.237 & 0.283 & 0.050 & -0.176 \\
\hline $\mathrm{Au}$ & 0.864 & -0.149 & -0.032 & -0.043 & 0.130 & 0.059 \\
\hline $\mathrm{Pb}$ & 0.900 & 0.092 & 0.075 & -0.040 & -0.170 & 0.010 \\
\hline $\mathrm{Bi}$ & 0.909 & 0.089 & 0.061 & -0.035 & -0.154 & 0.059 \\
\hline $\mathrm{Sr}$ & 0.308 & 0.399 & -0.220 & -0.267 & 0.270 & -0.084 \\
\hline
\end{tabular}

Bold font: the main contributing elements to different Factors.

Arsenic shows positive and scattered trends when plotted against $\mathrm{Cu}$ and Co (Figure 8f,g), which may result from the substitution of $\mathrm{As}$ for $\mathrm{S}$, where $\mathrm{Co}^{2+}, \mathrm{Ni}^{2+}, \mathrm{Cu}^{2+}$ and $\mathrm{Zn}^{2+}$ are the charge compensating ions of $\mathrm{As}^{2+}$ that enter the interstitial lattice position [28]. Arsenic could also enter the pyrite lattice through coupled substitution with $\mathrm{Au}\left(\mathrm{Au}^{+}+\mathrm{As}^{3+} \leftrightarrow 2 \mathrm{Fe}^{2+}\right)$ [28]; however, the contents of $\mathrm{Au}$ are relatively low, and it is difficult to prove its existing state with As. Arsenic and Sb contents in 
pyrite decrease with increasing degree of crystallization (i.e., that are higher in anhedral pyrite but lower in euhedral pyrite) [41], which may result from the preference of As and Sb to substitute for S in low-temperature fluids where pyrite crystallizes rapidly [36,42]. Arsenic and Sb contents in PyIII are higher than those in PyI and PyII (Figures 5 and 8h). This could be related to the rapid crystallization of PyIII that resulted from sharp physicochemical condition changes in the ore-forming fluid during stage II and stage III mineralization.
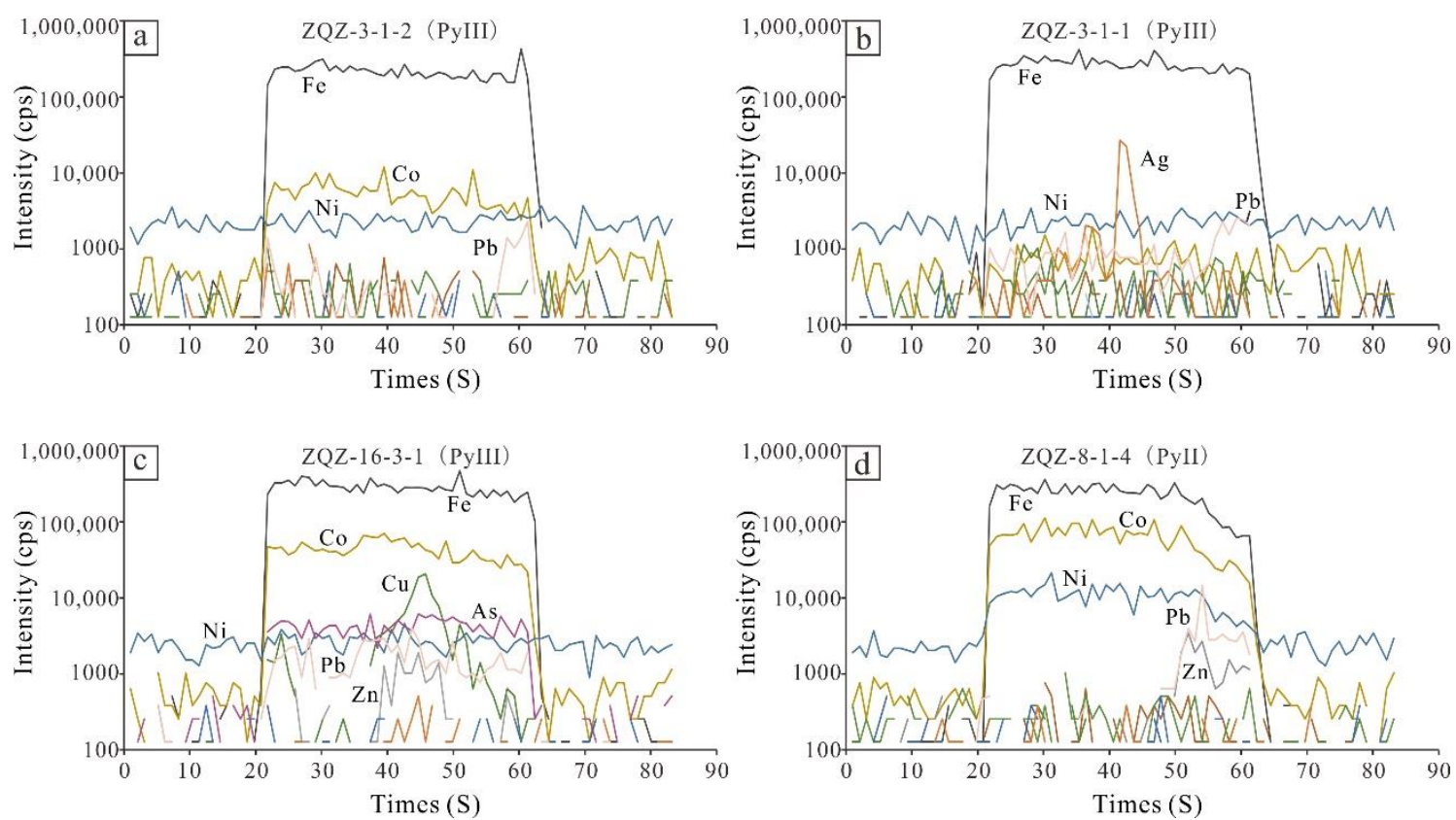

Figure 7. Examples of time-resolved LA-ICP-MS depth profiles for pyrite in the Zhangquanzhuang deposit. (a) Ablation profile for PyIII of spot ZQZ-3-1-2, showing smooth traces for Fe, Co and Ni; (b) ablation profile for PyIII of spot ZQZ-3-1-1, showing a micro-sized inclusion of silver minerals; (c) ablation profile for PyIII of spot ZQZ-16-3-1, showing smooth traces for Co, Ni and As, and a large inclusion of chalcopyrite with elevated Zn; (d) ablation profile for PyII of spot ZQZ-8-1-4, showing smooth traces for $\mathrm{Fe}, \mathrm{Co}$ and $\mathrm{Ni}$, and an inclusion of sphalerite with elevated $\mathrm{Pb}$.

Selenium could substitute for $S$ in pyrite, and its concentration is controlled by temperature, $\mathrm{pH}$ and $\Sigma$ Se/S ratio of hydrothermal fluids [31]. Selenium dissolution in fluids decreases with increasing temperature, and is nearly completely removed from the fluid phase as $\mathrm{H}_{2} \mathrm{Se}$ at temperatures above $300{ }^{\circ} \mathrm{C}[35,43]$. Therefore, Se content in pyrite increases as the fluid temperature decreases and could; thus, be used as a Se-in-pyrite thermometer $[44,45]$. Selenium contents in PyI, PyII and PyIII are uniform, indicating the consistent temperature of ore-forming fluids from stages I to III.

Tellurium could occur as $\mathrm{S}$ substitution or as telluride nanoparticles in pyrite $[35,44]$. Its contents in pyrite seem to be temperature independent and increase with decreasing $f \mathrm{O}_{2}$ of the fluid [44], and fluid boiling would lead to partitioning of Te into the vapor phase [46], resulting in low contents in pyrite [47]. Tellurium contents in PyI are higher than those in PyII and PyIII, which may be related to the boiling of hydrothermal fluid (cf. Section 6.4.2).

\subsection{Sulfur Isotope Fractionation}

The in-situ $\delta^{34} \mathrm{~S}_{\mathrm{H} 2 \mathrm{~S}}$ values of the ore-forming fluid range from 0.9 to $6.07 \%$, which are consistent with the bulk sulfide $\delta^{34} S$ reported by Zhen et al. (2020) [14]. The in-situ $\delta^{34} S_{\mathrm{H} 2 \mathrm{~S}}$ values of stages I and II are slightly higher than those of stage III (Figure 6). Mechanisms that could lead to variations in sulfur isotopes include (1) mixing with light sulfur enriched fluids; (2) an increase in $f \mathrm{O}_{2}$; (3) a decrease in temperature or $\mathrm{pH}$; and (4) fractionation of isotopes between coprecipitated sulfides or 
sulfide-sulfate $[5,34,48]$. In our study case, firstly, the decrease in temperature could not lead to precipitation of sphalerite (Section 6.4.2) and fluid inclusions in stages II and III have coincident homogeneous temperatures [8], which expels significant cooling from stage II to stage III; secondly, pyrite would be relatively more enriched in ${ }^{34} \mathrm{~S}$ compared with galena and chalcopyrite, which preferred higher ${ }^{32} S$ during precipitation [26], and led to higher $\delta^{34} S$ values of pyrite; however, $\delta^{34} S$ values of PyIII are lower than those of PyI and PyII, indicating that the lower $\delta^{34} \mathrm{~S}_{\mathrm{H} 2 \mathrm{~S}}$ values are not the result of fractionation of isotopes between coprecipitated sulfides; thirdly, mineral composition and isotope evidence [8,14] do not support the existence of fluid mixing in stage III. We argue that the lower $\delta^{34} \mathrm{~S}_{\mathrm{H} 2 \mathrm{~S}}$ values are more likely derived from the increase in fluid $f \mathrm{O}_{2}$ and/or the precipitation of minor sulfate.
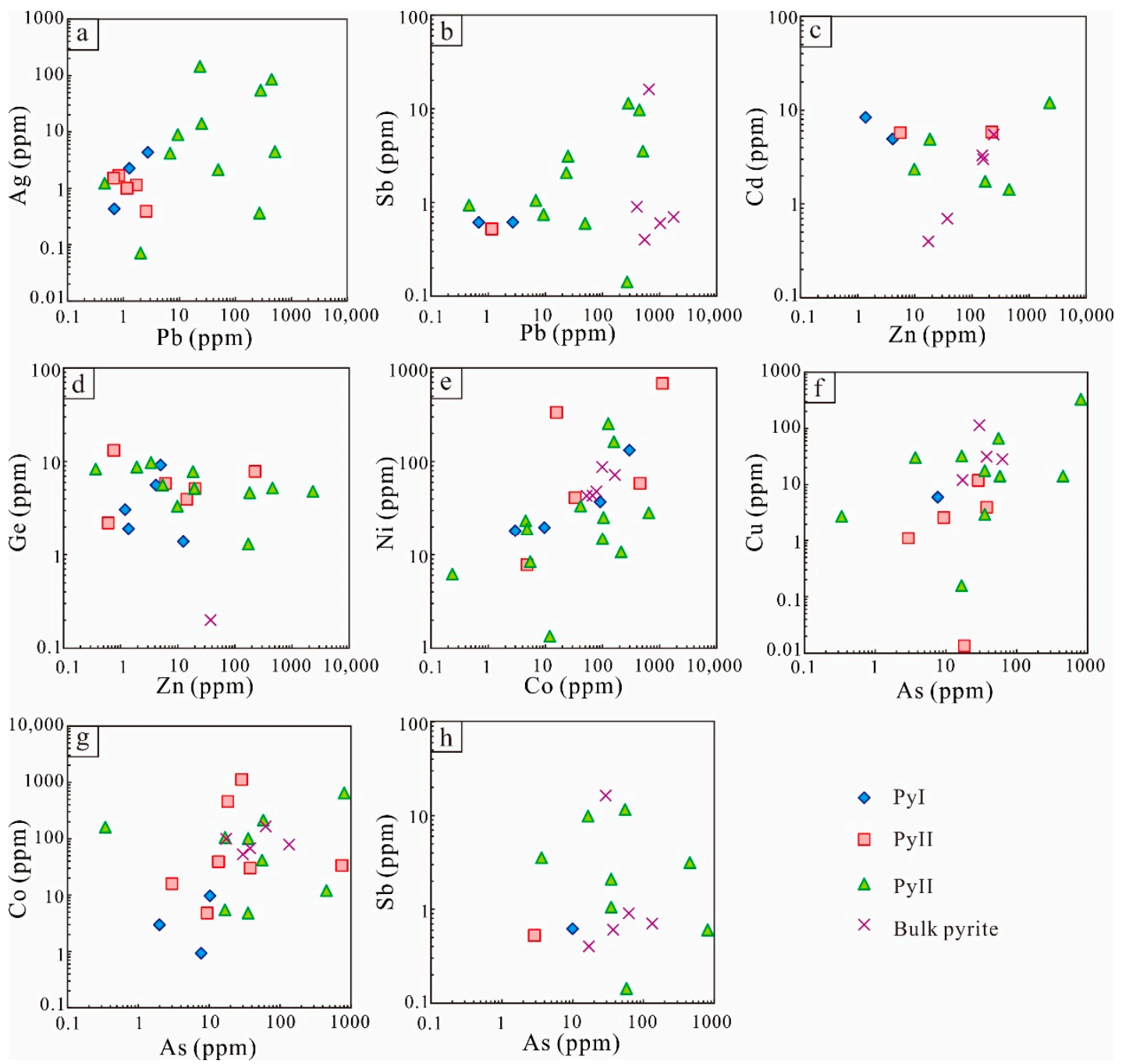

Figure 8. Binary plots of selected trace element concentrations (in ppm) for pyrite from the Zhangquanzhuang gold deposit. (a) $\mathrm{Pb} / \mathrm{Ag}$; (b) $\mathrm{Pb} / \mathrm{Sb}$; (c) $\mathrm{Zn} / \mathrm{Cd}$; (d) $\mathrm{Zn} / \mathrm{Ge}$; (e) $\mathrm{Co} / \mathrm{Ni}$; (f) $\mathrm{As} / \mathrm{Cu}$; (g) As/Co; (h) As/Sb.

\subsection{Physicochemical Conditions of Ore-Forming Fluid and Mechanisms of Ore Deposition}

\subsubsection{Physicochemical Conditions of Ore-Forming Fluid}

Trace element concentrations in pyrite are strongly influenced by environmental conditions, and they are commonly used to evaluate elemental concentrations and physicochemical conditions (redox, $\mathrm{pH}$, temperature and oxygen fugacity) of ore-forming fluids [30,32]. Combined with trace element and sulfur isotope compositions of pyrite, in parallel with paragenetic sequences of mineral 
deposition, physicochemical conditions of ore-forming fluid and mechanisms of ore precipitation of the Zhangquanzhuang gold deposit can be discussed.

Different elements are transported as different aqueous complexes in the fluids, which is dependent on temperature, redox conditions and the availability of ligands. For example, $\mathrm{Cu}, \mathrm{Pb}, \mathrm{Zn}, \mathrm{Ag}$ and $\mathrm{Au}$ are transported as chloride, bisulfide and hydroxide complexes under different temperature and redox conditions [49-54]; $\mathrm{Sb}$ is mainly transported as hydroxide-chloride complexes and thioarsenite or thioantimonite species in hydrothermal fluids [49,55]; and Bi is mainly transported as hydroxide complexes at high temperatures [56]. However, recent studies show that ligand concentrations strongly affect metal species in fluids $[50,57,58]$, and bisulfide complexes are more important for metal transport in magmatic hydrothermal fluids [50]. Fluid inclusion studies show that ore fluids in the Zhangquanzhuang gold deposit were moderate to high temperature and had low to moderate salinity, and sulfate was the dominant anion, followed by $\mathrm{Cl}^{-}$and $\mathrm{F}^{-}$[59]. Therefore, we argue that bisulfide complexes were the predominant metal species in the Zhangquanzhuang ore fluids.

The sulfide mineral assemblages and trace element concentrations in pyrite show that large amounts of $\mathrm{Cu}, \mathrm{Pb}, \mathrm{Zn}, \mathrm{Ag}$ and $\mathrm{Au}$ precipitated during the evolution from stage II to stage III. To constrain the various physicochemical parameters and interpret the mineral depositions, phase stability relationships were established using SUPCRT92 [60] with the database of Zimmer et al. (2016) [61]. The thermodynamic properties of the $\mathrm{Pb}$ complexes were taken from Sverjensky et al. (1997) [62] and Zn complexes were compiled from Mei et al. $(2015,2016)[58,63]$. Based on the fact that the thermodynamic equilibrium constants of $\mathrm{Pb}$ and $\mathrm{Zn}$ are limited at high temperatures and low pressure, and the contribution of the pressure change to the reactions can be neglected [58,63], we chose 200 bars for the $\mathrm{Fe}-\mathrm{Cu}-\mathrm{O}-\mathrm{S}$ system to fit the $\mathrm{Pb}$ and $\mathrm{Zn}$ data. All solid phases are considered to have ideal solution behavior. The following reactions were considered possible ore deposition processes (Equations (1)-(5)):

$$
\begin{gathered}
\mathrm{Zn}(\mathrm{HS})_{2(\mathrm{aq})}^{0}=\mathrm{ZnS}_{(\mathrm{s})}+\mathrm{HS}^{-}{ }_{(\mathrm{aq})}+\mathrm{H}^{+}{ }_{(\mathrm{aq})} \\
\mathrm{Pb}(\mathrm{HS})_{2(\mathrm{aq})}^{0}=\mathrm{PbS}_{(\mathrm{s})}+\mathrm{HS}^{-}{ }_{(\mathrm{aq})}+\mathrm{H}^{+}{ }_{(\mathrm{aq})} \\
\mathrm{Cu}(\mathrm{HS})_{2(\mathrm{aq})}^{-}+\mathrm{Fe}^{2+}{ }_{(\mathrm{aq})}=\mathrm{CuFeS}_{2(\mathrm{~s})}+\mathrm{H}^{+}{ }_{(\mathrm{aq})}+0.5 \mathrm{H}_{2(\mathrm{~g})} \\
\mathrm{Au}(\mathrm{HS})_{2(\mathrm{aq})}^{-}+0.5 \mathrm{H}_{2} \mathrm{O}_{(\mathrm{aq})}=\mathrm{Au}_{(\mathrm{s})}+2 \mathrm{HS}^{-}{ }_{(\mathrm{aq})}+\mathrm{H}^{+}{ }_{(\mathrm{aq})}+0.25 \mathrm{O}_{2(\mathrm{~g})} \\
\mathrm{Ag}(\mathrm{HS})_{(\mathrm{aq})}^{0}+0.5 \mathrm{H}_{2} \mathrm{O}_{(\mathrm{aq})}=\mathrm{Ag}_{(\mathrm{s})}+\mathrm{HS}^{-}{ }_{(\mathrm{aq})}+\mathrm{H}^{+}{ }_{(\mathrm{aq})}+0.25 \mathrm{O}_{2(\mathrm{~g})}
\end{gathered}
$$

Mineral assemblages in stages I and II are not sufficient to constrain the physicochemical conditions of ore-forming fluids. In stage III, native gold, electrum, pyrite, chalcopyrite, galena, sphalerite and tetrahedrite precipitated at the same time [14]. The $\mathrm{pH}$ and $\log f \mathrm{O}_{2}$ can be constrained at $\alpha_{\Sigma \mathrm{S}}=0.1$ and $\alpha_{\mathrm{Zn}}=10 \mathrm{ppm}$, and the calculated values range from 4.1 to 5.2 and -36.9 to -32.1 , respectively (Figure 9a).

\subsubsection{Mechanisms of Mineral Deposition}

Cooling, sulfidation, decompression, boiling and mixing with other fluids are the mechanisms that trigger the deposition of metal elements $[33,46,64,65]$.

The decreasing temperature of the fluid resulted in metal precipitation. Figure $9 a, c$ shows that decreasing temperature could not significantly enlarge the stable areas of sphalerite, especially for fluids with low Zn concentrations. Therefore, cooling was not the dominant mechanism that led to the precipitation of sulfides in stage III. 

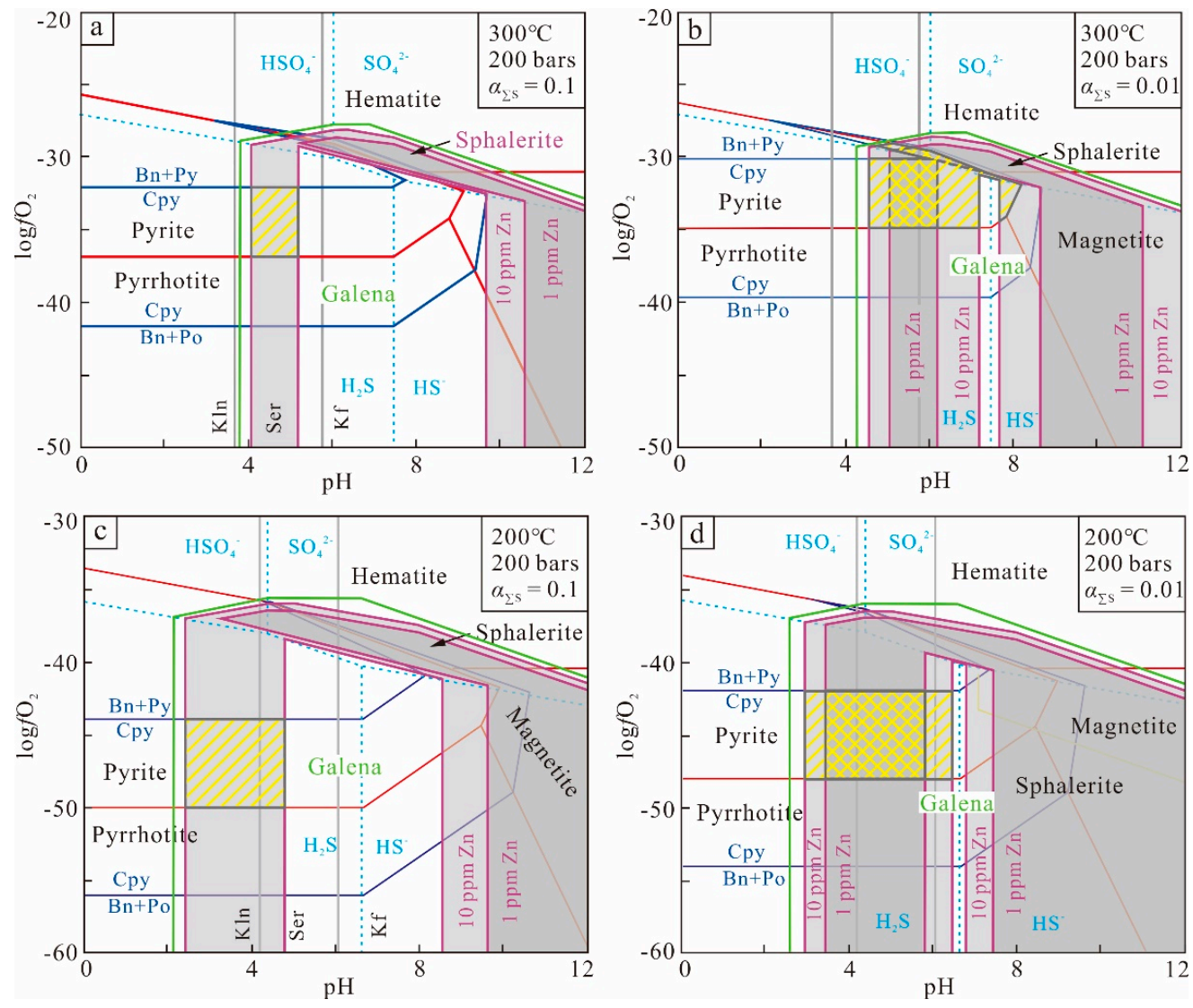

Figure 9. $\log \mathrm{fO}_{2}$ vs. $\mathrm{pH}$ diagram showing stability relationships in the $\mathrm{Fe}-\mathrm{Cu}-\mathrm{Pb}-\mathrm{Zn}-\mathrm{O}-\mathrm{S}$ system. (a) Conditions of $300{ }^{\circ} \mathrm{C}, 200$ bars and $\alpha_{\sum \mathrm{S}}=0.1$; (b) conditions of $300{ }^{\circ} \mathrm{C}, 200$ bars and $\alpha_{\sum \mathrm{S}}=0.01$; (c) conditions of $200{ }^{\circ} \mathrm{C}, 200$ bars and $\alpha_{\sum \mathrm{S}}=0.1$; (d) conditions of $200{ }^{\circ} \mathrm{C}, 200$ bars and $\alpha_{\sum \mathrm{S}}=0.01$. The blue dashed lines represent the predominance boundaries of the aqueous sulfur species. The red solid lines represent boundaries of $\mathrm{Fe}-\mathrm{O}-\mathrm{S}$ minerals and the blue solid lines are the stability boundaries for chalcopyrite and bornite. The thicker green and purple lines are the stability boundaries for galena and sphalerite, respectively. The sericite, kaolinite and $\mathrm{K}$-feldspar equilibria boundaries are shown as grey solid lines. The grey areas represent stability fields for sphalerite at different Zn content conditions, and the yellow areas are the fields of coexisting of pyrite, chalcopyrite, galena and sphalerite. All phase diagrams were constructed assuming $\alpha_{\mathrm{Cl}}=0.1$ and $\alpha_{\mathrm{K}+}=0.01$. Abbreviations: $\mathrm{Bn}=$ bornite, Cpy = chalcopyrite, $\mathrm{Kln}=$ kaolinite, $\mathrm{Kf}=\mathrm{K}$-feldspar, $\mathrm{Po}=$ pyrrhotite, $\mathrm{Py}=$ pyrite, Ser $=$ sericite .

Precipitation of pyrite would consume large amounts of sulfur and decrease the activity of $\sum S$ in the ore fluid [66]. Figure 9 shows that a decrease in $\sum S$ in the fluid would significantly enlarge the stable areas of sphalerite and promote sulfide precipitation. We propose, therefore, that sulfidation in stage II should have played an important role during sulfide deposition in stage III.

Decreasing pressure triggers local boiling of the hydrothermal fluid and leads to saturation of dissolved metals in the fluid, an increase in $\mathrm{pH}$ and a decrease in temperature [33,65]. This process resulted in precipitation of $\mathrm{Ag}, \mathrm{Cu}, \mathrm{Zn}, \mathrm{Pb}$ and $\mathrm{Au}$ together with pyrite, as well as crushing of previously formed pyrite $[33,65]$, which is similar to the textures of stage III samples (Figure 4j-1). Boiling would decrease the activity of $\mathrm{HS}^{-}$and promote $\mathrm{H}_{2}, \mathrm{O}_{2}$ and $\mathrm{H}_{2} \mathrm{~S}$ fractionation into the vapor, driving reactions (1) to (5) to the right and promoting precipitation of sulfides, silver and gold [45]. Releasing $\mathrm{H}_{2}$ and $\mathrm{H}_{2} \mathrm{~S}$ into the vapor phase causes the increments in $\mathrm{pH}$ and the sulfate/sulfide ratio in the fluid, and the dominant sulfur species transform from $\mathrm{H}_{2} \mathrm{~S}$ to $\mathrm{HS}^{-}$and then to $\mathrm{SO}_{4}{ }^{2-}$ (Figure 9a) [46]. This process leads to the fractionation of $\delta^{34} S$ between coprecipitated sulfide-sulfate, resulting in lower $\delta^{34} S$ values in stage III sulfides. Simultaneously, boiling could release Te from the hydrothermal fluid into the vapor phase as $\mathrm{H}_{2} \mathrm{Te}$, and result in the depletion of Te contents in PyIII, although this phenomenon is 
not obvious compared with that in Te-enriched gold deposits [3,47]. Román et al. (2019) [30] stated that boiling would lead to high concentrations of $\mathrm{As}, \mathrm{Cu}, \mathrm{Pb}, \mathrm{Ag}$ and $\mathrm{Au}$ in pyrite, on the contrary; in contrast, Co enrichment is not associated with boiling. Ag/Co ratios in pyrite could be a criterion to distinguish boiling and non-boiling/gentle boiling of ore-forming fluids. In the Zhangquanzhuang deposit, As, $\mathrm{Cu}, \mathrm{Pb}, \mathrm{Ag}$, Au contents and Ag/Co ratios in PyIII are significantly higher than those in PyI and PyII, implying the existence of fluid boiling during mineral deposition. Therefore, boiling derived from decompression may be the potential mechanism that led to mineral precipitation and sulfur isotope and trace element partitions in stage III.

The addition of metals in ore-forming fluid triggered the deposition of sulfides (Figure 9). However, the $\mathrm{S}-\mathrm{Pb}-\mathrm{He}-\mathrm{Ar}$ isotope compositions were stable during the evolution from stage II to stage III [14], indicating that no external fluid was added into the ore-forming fluid, which annuls the possibility of adding metals.

In summary, we propose that sulfidation and boiling derived from decompression were likely the dominant mechanisms that led to the precipitation of sulfides and $\mathrm{Au}-\mathrm{Ag}$ minerals during evolution from stage II to stage III, which also controlled the fractionation of isotopes and trace elements in sulfides.

\subsection{Comparison with Other Gold Deposits in the Zhangjiakou District}

There are many gold deposits in the Zhangjiakou district, including the Dongping, Huantualiang, Zhongshangou, Hougou, Hanjiagou and Xiaoyinpan deposits. The deposits hosted in the hydrothermally altered Shuiquangou syenitic complex are called the "Dongping-type" deposits, while the deposits hosted in the Archean Sanggan Group metamorphic rocks are called the "Xiaoyinggpan-type" deposits. These deposits have common features, including low-sulfide volumes, enrichment in tellurides and negative sulfur isotopes (Table 3) [5,67], and they are regarded to have formed within the same mineral system. These Te-Au-Ag deposits are genetically related to the Devonian Shuiquangou syenite, and their Te came from a magmatic source $[5,68]$. Compared with these Te-Au-Ag deposits, the Zhangquanzhuang gold deposit is enriched in sulfides, with rare tellurides and zero to positive sulfur isotope compositions (Table 3) [14]. These differences indicate that the Zhangquanzhuang gold deposit was formed in a mineral system that is different from the one that formed the Te-Au-Ag deposits, and thus should belong to the "Zhangquanzhuang-type" deposit [69]. Te-poor but metal-rich hydrothermal fluids and Sanggan metamorphic rocks contributed to the formation of the Zhangquanzhuang gold deposit, which may be related to a mantle-derived fluid and the addition of crustal $\mathrm{K}$ into the ore-forming system [14].

Table 3. Comparation of geological characteristics of different gold deposits.

\begin{tabular}{|c|c|c|c|c|}
\hline Deposit Type & Zhangquanzhuang-Type & Dongping-Type & Xiaoyingpan-Type & Jiaodong Deposits \\
\hline Wall rock & metamorphic rocks & syenitic complex & metamorphic rocks & metamorphic rocks \\
\hline Ore type & $\begin{array}{c}\text { sulfide-enriched quartz } \\
\text { veins }\end{array}$ & $\begin{array}{l}\text { low-sulfide quartz } \\
\text { veins }\end{array}$ & $\begin{array}{l}\text { low-sulfide quartz } \\
\text { veins }\end{array}$ & $\begin{array}{l}\text { sulfide-enriched } \\
\text { feldspar-quartz veins }\end{array}$ \\
\hline $\begin{array}{l}\text { S-isotopes values } \\
\text { range }\end{array}$ & zero to positive & negative to zero & negative & zero to positive \\
\hline $\begin{array}{c}\text { Mineral } \\
\text { assemblages }\end{array}$ & $\begin{array}{l}\text { quartz, k-feldspar, } \\
\text { sulfides, native gold, } \\
\text { electrum, fluorite }\end{array}$ & $\begin{array}{l}\text { quartz, k-feldspar, } \\
\text { sulfides, native gold, } \\
\text { Te-Au-Ag minerals, } \\
\text { Te-Bi-Pb minerals }\end{array}$ & $\begin{array}{l}\text { quartz, k-feldspar, } \\
\text { sulfides, native gold, } \\
\text { Te-Au-Ag minerals }\end{array}$ & $\begin{array}{l}\text { pyrite, chalcopyrite, } \\
\text { galena, sphalerite, } \\
\text { electrum, native gold }\end{array}$ \\
\hline Gold grade & 1.2 to $3.6 \mathrm{~g} / \mathrm{t}$ & average of $6 \mathrm{~g} / \mathrm{t}$ & average of $9.7 \mathrm{~g} / \mathrm{t}$ & 2 to $6 \mathrm{~g} / \mathrm{t}$ \\
\hline
\end{tabular}

\section{Conclusions}

(1) Pyrite in stage I contains high Te, and low $\mathrm{Zn}$ and As contents; pyrite in stage II has the highest $\mathrm{Co}$ and Ni contents; pyrite in stage III contains high concentrations of $\mathrm{Cr}, \mathrm{Zn}, \mathrm{Pb}, \mathrm{Ag}, \mathrm{Cu}, \mathrm{Sb}$, $\mathrm{Bi}$ and $\mathrm{Au}$. The calculated in-situ $\delta^{34} \mathrm{~S}_{\mathrm{H} 2 \mathrm{~S}}$ values range from $0.9 \%$ o to $6.1 \%$, and the values in 
stages I and II are higher than those in stage III, which is due to the increase in fluid $f \mathrm{O}_{2}$ and/or the precipitation of minor sulfate.

(2) Bisulfide complexes were the predominant metal species during gold mineralization stages in the Zhangquanzhuang ore fluids, and the $\mathrm{pH}$ and $\log f \mathrm{O}_{2}$ of stage III were constrained to range from 4.1 to 5.2 and -36.9 to -32.1 , respectively.

(3) Sulfidation and boiling derived from decompression were the dominant mechanisms that led to the precipitation of sulfides and $\mathrm{Au}-\mathrm{Ag}$ minerals during the evolution from stage II to stage III, which also controlled the distribution of isotopes and trace elements in sulfides.

(4) The Zhangquanzhuang gold deposit was formed in a mineral system that was different from the system that formed the Dongping and Xiaoyingpan Te-Au-Ag deposits and should; thus, be called the "Zhangquanzhuang-type" deposit, representing a third gold deposit type in the Zhangjiakou ore field.

Supplementary Materials: The following are available online at http://www.mdpi.com/2075-163X/10/12/1089/s1, Table S1: LA-ICP-MS in-situ trace element compositions (ppm) of pyrite in the Zhangquanzhuang gold deposit, Table S2: LA-MC-ICP-Ms in-situ sulfur isotope compositions of sulfides in the Zhangquanzhuang gold deposit, Table S3: Bulk trace element compositions (ppm) of pyrite in the Zhangquanzhuang gold deposit.

Author Contributions: Conceptualization and Methodology, S.Z., and D.W.; Investigation, S.Z., D.W., Z.Z., and J.W.; Experimental Analysis, Z.Z., and J.W.; Writing-Original Draft Preparation, S.Z., Y.L. and D.W.; Writing-Review and Editing, D.W., X.Y. and Q.W.; Plotting, S.Z., Z.Z., and J.W. All authors have read and agreed to the published version of the manuscript.

Funding: This research was funded by China Geological Survey Project, grant numbers DD20160052, DD20190159, and DD20190166, the National Natural Science Foundation of China, grant number 42003032.

Acknowledgments: We are sincerely thankful to the Zhangquanzhuang Gold Mine of the Shengde Mining in Xuanhua.

Conflicts of Interest: The authors declare no conflict of interest.

\section{References}

1. Hart, C.J.R.; Goldfarb, R.J.; Qiu, Y.; Snee, L.; Miller, L.D.; Miller, M.L. Gold deposits of the northern margin of the North China Craton: Multiple late Paleozoic-Mesozoic mineralizing events. Miner. Deposita 2002, 37, 326-351. [CrossRef]

2. Deng, J.; Wang, Q. Gold mineralization in China: Metallogenic provinces, deposit types and tectonic framework. Gondwana Res. 2016, 36, 219-274. [CrossRef]

3. Cook, N.J.; Ciobanu, C.L.; Mao, J. Textural control on gold distribution in As-free pyrite from the Dongping, Huangtuliang and Hougou gold deposits, North China Craton (Hebei Province, China). Chem. Geol. 2009, 264, 101-121. [CrossRef]

4. Mao, J.W.; Li, Y.Q.; Goldfarb, R.; He, Y.; Zaw, K. Fluid Inclusion and Noble Gas Studies of the Dongping Gold Deposit, Hebei Province, China: A Mantle Connection for Mineralization? Econ. Geol. 2003, 98, 517-534. [CrossRef]

5. Wang, D.; Liu, J.; Zhai, D.; Carranza, E.J.M.; Wang, Y.; Zhen, S.; Wang, J.; Wang, J.; Liu, J.; Zhang, F. Mineral paragenesis and ore-forming processes of the dongping gold deposit, Hebei Province, China. Resour. Geol. 2019, 69, 287-313. [CrossRef]

6. Jiang, S.H.; Nie, F.J. A comparison study on geological and geochemical features and ore genesis of the Xiaoyingpan and Dongping gold deposits, Hebei. Gold Geol. 1998, 4, 12-24. (In Chinese)

7. Nie, F.-J. Geology and origin of the dongping alkalic-type gold deposit, Northern Hebei Province, People's Republic of China. Resour. Geol. 1998, 48, 139-158. [CrossRef]

8. Yin, J.Z.; Shi, H.Y. Geology of Gold Ore Deposits in Zhangjiakou-Xuanhua Region, Hebei Province, China; Geological Publishing House: Beijing, China, 1995.

9. Yin, J.Z.; Shi, H.Y. Mineralogy characteristics of quartz in Zhangquanzhuang gold deposit, northwestern Hebei Province. Geoscience 1994, 8, 459-465. (In Chinese)

10. Shui, L.S. Research on geological-tectonic feature and regularity of the concentration of gold mineralization of Zhang-Quan-Zhuang gold deposit. Gold 2000, 21, 10-13. (In Chinese) 
11. Shui, L.S.; He, P.S. The features of gold-containing quartz vein in the gold mine at Zhang Quan. J. Hebei Inst. Technol. 1998, 20, 89-92. (In Chinese)

12. Li, C.Y.; Shi, L.D. The elemental geochemistry and exploration significance of Zhangquanzhuang gold deposit. J. Precious Met. Geol. 1999, 8, 223-226. (In Chinese)

13. Yin, J.Z.; Shi, H.Y. The typomorphic characteristics and their genetic meaning on the pyrite of Zhang-Quan-Zhuang gold deposit in Hebei Province. Gold 1994, 15, 6-11. (In Chinese)

14. Zhen, S.; Wang, Q.; Wang, D.; Carranza, E.J.M.; Liu, J.; Pang, Z.; Cheng, Z.; Xue, J.; Wang, J.; Zha, Z. Genesis of the Zhangquanzhuang gold deposit in the northern margin of North China Craton: Constraints from deposit geology and ore isotope geochemistry. Ore Geol. Rev. 2020, 122, 103511. [CrossRef]

15. Zhang, S.H.; Zhao, Y.; Liu, J.; Hu, J.M.; Chen, Z.L.; Pei, J.L.; Chen, Z.Y.; Zhou, J.X. Emplacement depths of the Late Paleozoic-Mesozoic granitoid intrusions from the northern North China block and their tectonic implications. Acta Geol. Sin. 2007, 23, 625-638. (In Chinese)

16. Zhai, M.; Santosh, M. Metallogeny of the North China Craton: Link with secular changes in the evolving Earth. Gondwana Res. 2013, 24, 275-297. [CrossRef]

17. Li, C.J.; Bao, Z.W.; Zhao, Z.Z.; Qiao, Y.L. Zircon U-Pb age and Hf isotopic compositions of the granitic gneisses from the Sanggan complex in the Zhangjiakou area: Constraints on the early evolution of North China Craton. Acta Geol. Sin. 2012, 28, 1057-1072. (In Chinese)

18. Liu, Z.F.; Wang, J.M.; Lv, J.B.; Zheng, G.S. Geological features and age of the Wenquan rapakivi granite, Chicheng County, Hebei. Geol. China 2006, 33, 1052-1058. (In Chinese)

19. Luo, Z.K.; Miao, L.C.; Guan, K.; Qiu, Y.S.; Qiu, Y.M.; McNaughton, N.J.; Groves, D.I. SHRIMP chronological study of Shuiquangou intrusive body in Zhangiakou area, Hebei province and its geochemical significance. Geochimica 2001, 30, 116-122. (In Chinese)

20. Miao, L.; Qiu, Y.; McNaughton, N.; Luo, Z.; Groves, D.; Zhai, Y.; Fan, W.; Zhai, M.; Guan, K. SHRIMP U-Pb zircon geochronology of granitoids from Dongping area, Hebei Province, China: Constraints on tectonic evolution and geodynamic setting for gold metallogeny. Ore Geol. Rev. 2002, 19, 187-204. [CrossRef]

21. Jiang, N.; Liu, Y.; Zhou, W.; Yang, J.; Zhang, S.Q. Derivation of Mesozoic adakitic magmas from ancient lower crust in the North China craton. Geochim. Cosmochim. Acta 2007, 71, 2591-2608. [CrossRef]

22. Jiang, N.; Zhang, S.; Zhou, W.; Liu, Y. Origin of a Mesozoic granite with A-type characteristics from the North China craton: Highly fractionated from I-type magmas? Contrib. Miner. Pet. 2009, 158, 113-130. [CrossRef]

23. Liu, Y.; Hu, Z.; Gao, S.; Günther, D.; Xu, J.; Gao, C.; Chen, H. In situ analysis of major and trace elements of anhydrous minerals by LA-ICP-MS without applying an internal standard. Chem. Geol. 2008, 257, $34-43$. [CrossRef]

24. Chen, L.; Chen, K.; Bao, Z.; Liang, P.; Sun, T.; Yuan, H. Preparation of standards for in situ sulfur isotope measurement in sulfides using femtosecond laser ablation MC-ICP-MS. J. Anal. At. Spectrom. 2017, 32, 107-116. [CrossRef]

25. Li, H.; Wang, Z.; Li, F. Ideal models of superimposed primary halos in hydrothermal gold deposits. J. Geochem. Explor. 1995, 55, 329-336. [CrossRef]

26. Ohmoto, H. Systematics of sulfur and carbon isotopes in hydrothermal ore deposits. Econ. Geol. 1972, 67, 551-578. [CrossRef]

27. Deditius, A.P.; Utsunomiya, S.; Reich, M.; Kesler, S.E.; Ewing, R.C.; Hough, R.M.; Walshe, J. Trace metal nanoparticles in pyrite. Ore Geol. Rev. 2011, 42, 32-46. [CrossRef]

28. Deditius, A.P.; Utsunomiya, S.; Renock, D.; Ewing, R.C.; Ramana, C.V.; Becker, U.; Kesler, S.E. A proposed new type of arsenian pyrite: Composition, nanostructure and geological significance. Geochim. Cosmochim. Acta 2008, 72, 2919-2933. [CrossRef]

29. Meng, Y.-M.; Hu, R.-Z.; Huang, X.-W.; Gao, J.-F.; Sasseville, C. The origin of the carbonate-hosted Huize $\mathrm{Zn}-\mathrm{Pb}-\mathrm{Ag}$ deposit, Yunnan province, SW China: Constraints from the trace element and sulfur isotopic compositions of pyrite. Miner. Pet. 2019, 113, 369-391. [CrossRef]

30. Román, N.; Reich, M.; Leisen, M.; Morata, D.; Barra, F.; Deditius, A.P. Geochemical and micro-textural fingerprints of boiling in pyrite. Geochim. Cosmochim. Acta 2019, 246, 60-85. [CrossRef]

31. Grant, H.L.; Hannington, M.D.; Petersen, S.; Frische, M.; Fuchs, S.H. Constraints on the behavior of trace elements in the actively-forming TAG deposit, Mid-Atlantic Ridge, based on LA-ICP-MS analyses of pyrite. Chem. Geol. 2018, 498, 45-71. [CrossRef] 
32. Reich, M.; Deditius, A.; Chryssoulis, S.; Li, J.-W.; Ma, C.-Q.; Parada, M.A.; Barra, F.; Mittermayr, F. Pyrite as a record of hydrothermal fluid evolution in a porphyry copper system: A SIMS/EMPA trace element study. Geochim. Cosmochim. Acta 2013, 104, 42-62. [CrossRef]

33. Velasquez, G.; Beziat, D.; Salvi, S.; Siebenaller, L.; Borisova, A.Y.; Pokrovski, G.S.; De Parseval, P. Formation and deformation of pyrite and implications for gold mineralization in the El Callao District, Venezuela. Econ. Geol. 2013, 109, 457-486. [CrossRef]

34. Voute, F.; Hagemann, S.G.; Evans, N.J.; Villanes, C. Sulfur isotopes, trace element, and textural analyses of pyrite, arsenopyrite and base metal sulfides associated with gold mineralization in the Pataz-Parcoy district, Peru: Implication for paragenesis, fluid source, and gold deposition mechanisms. Miner. Deposita 2019, 54, 1077-1100. [CrossRef]

35. Huston, D.L.; Sie, S.H.; Suter, G.F.; Cooke, D.R.; Both, R.A. Trace elements in sulfide minerals from eastern australian volcanic-hosted massive sulfide deposits: Part I. Proton microprobe analyses of pyrite, chalcopyrite, and sphalerite, and Part II. Selenium levels in Pyrite: Comparison with $\delta^{34} S$ values and implications for the source of sulfur in volcanogenic hydrothermal systems. Econ. Geol. 1995, 90, 1167-1196. [CrossRef]

36. Maslennikov, V.V.; Maslennikova, S.P.; Large, R.R.; Danyushevsky, L.V. Study of trace element zonation in vent chimneys from the Silurian Yaman-Kasy volcanic-hosted massive sulfide deposit (Southern Urals, Russia) using laser ablation-inductively coupled plasma mass spectrometry (LA-ICPMS). Econ. Geol. 2009, 104, 1111-1141. [CrossRef]

37. Keith, M.; Häckel, F.; Haase, K.M.; Schwarz-Schampera, U.; Klemd, R. Trace element systematics of pyrite from submarine hydrothermal vents. Ore Geol. Rev. 2016, 72, 728-745. [CrossRef]

38. Gregory, D.D.; Large, R.R.; Halpin, J.A.; Baturina, E.L.; Lyons, T.W.; Wu, S.; Danyushevsky, L.; Sack, P.J.; Chappaz, A.; Maslennikov, V.V.; et al. Trace element content of sedimentary pyrite in black shales. Econ. Geol. 2015, 110, 1389-1410. [CrossRef]

39. Bajwah, Z.U.; Seccombe, P.K.; Offler, R. Trace element distribution, Co:Ni ratios and genesis of the big cadia iron-copper deposit, new south wales, australia. Miner. Deposita 1987, 22, 292-300. [CrossRef]

40. Bralia, A.; Sabatini, G.; Troja, F. A revaluation of the $\mathrm{Co} / \mathrm{Ni}$ ratio in pyrite as geochemical tool in ore genesis problems. Miner. Deposita 1979, 14, 353-374. [CrossRef]

41. Wohlgemuth-Ueberwasser, C.C.; Viljoen, F.; Petersen, S.; Vorster, C. Distribution and solubility limits of trace elements in hydrothermal black smoker sulfides: An in-situ LA-ICP-MS study. Geochim. Cosmochim. Acta 2015, 159, 16-41. [CrossRef]

42. Ballantyne, J.M.; Moore, J.N. Arsenic geochemistry in geothermal systems. Geochim. Cosmochim. Acta 1988, 52, 475-483. [CrossRef]

43. Layton-Matthews, D.; Peter, J.M.; Scott, S.D.; Leybourne, M.I. Distribution, mineralogy, and geochemistry of selenium in felsic volcanic-hosted massive sulfide deposits of the Finlayson Lake District, Yukon Territory, Canada. Econ. Geol. 2008, 103, 61-88. [CrossRef]

44. Keith, M.; Smith, D.J.; Jenkin, G.R.; Holwell, D.A.; Dye, M.D. A review of Te and Se systematics in hydrothermal pyrite from precious metal deposits: Insights into ore-forming processes. Ore Geol. Rev. 2018, 96, 269-282. [CrossRef]

45. Mathieu, L. Detecting magmatic-derived fluids using pyrite chemistry: Example of the Chibougamau area, Abitibi Subprovince, Québec. Ore Geol. Rev. 2019, 114, 103127. [CrossRef]

46. Cooke, D.R.; McPhail, D.C. Epithermal Au-Ag-Te mineralization, Acupan, Baguio district, Philippines: Numerical simulations of mineral deposition. Econ. Geol. 2001, 96, 109-131.

47. Keith, M.; Smith, D.J.; Doyle, K.; Holwell, D.A.; Jenkin, G.R.T.; Barry, T.L.; Becker, J.; Rampe, J. Pyrite chemistry: A new window into Au-Te ore-forming processes in alkaline epithermal districts, Cripple Creek, Colorado. Geochim. Cosmochim. Acta 2020, 274, 172-191. [CrossRef]

48. Seal, R.R. Sulfur Isotope Geochemistry of Sulfide Minerals. Rev. Miner. Geochem. 2006, 61, 633-677. [CrossRef]

49. Seward, T.M.; Williams-Jones, A.E.; Migdisov, A.A. The chemistry of metal transport and deposition by ore-forming hydrothermal fluids. In Treatise on Geochemistry, 2nd ed.; Holland, H.D., Turekian, K.K., Eds.; Elsevier Science: Oxford, UK, 2014; pp. 29-57.

50. Zhong, R.; Brugger, J.; Chen, Y.; Li, W. Contrasting regimes of $\mathrm{Cu}, \mathrm{Zn}$ and $\mathrm{Pb}$ transport in ore-forming hydrothermal fluids. Chem. Geol. 2015, 395, 154-164. [CrossRef]

51. Stefánsson, A.; Seward, T.M. Gold(I) complexing in aqueous sulphide solutions to $500{ }^{\circ} \mathrm{C}$ at 500 bar. Geochim. Cosmochim. Acta 2004, 68, 4121-4143. [CrossRef] 
52. Stefánsson, A.; Seward, T.M. Stability of chloridogold(I) complexes in aqueous solutions from 300 to $600{ }^{\circ} \mathrm{C}$ and from 500 to 1800 bar. Geochim. Cosmochim. Acta 2003, 67, 4559-4576. [CrossRef]

53. Stefánsson, A.; Seward, T.M. The hydrolysis of gold(I) in aqueous solutions to $600{ }^{\circ} \mathrm{C}$ and 1500 bar. Geochim. Cosmochim. Acta 2003, 67, 1677-1688. [CrossRef]

54. Stefánsson, A.; Seward, T.M. Experimental determination of the stability and stoichiometry of sulphide complexes of silver(I) in hydrothermal solutions to $400{ }^{\circ} \mathrm{C}$. Geochim. Cosmochim. Acta 2003, 67, 1395-1413. [CrossRef]

55. Pokrovski, G.S.; Roux, J.; Harrichoury, J.-C. Fluid density control on vapor-liquid partitioning of metals in hydrothermal systems. Geology 2005, 33, 657-660. [CrossRef]

56. Tooth, B.; Etschmann, B.; Pokrovski, G.S.; Testemale, D.; Hazemann, J.-L.; Grundler, P.V.; Brugger, J. Bismuth speciation in hydrothermal fluids: An X-ray absorption spectroscopy and solubility study. Geochim. Cosmochim. Acta 2013, 101, 156-172. [CrossRef]

57. Pokrovski, G.S.; Borisova, A.Y.; Bychkov, A.Y. Speciation and Transport of metals and metalloids in geological vapors. Rev. Miner. Geochem. 2013, 76, 165-218. [CrossRef]

58. Mei, Y.; Etschmann, B.; Liu, W.; Sherman, D.M.; Testemale, D.; Brugger, J. Speciation and thermodynamic properties of zinc in sulfur-rich hydrothermal fluids: Insights from ab initio molecular dynamics simulations and X-ray absorption spectroscopy. Geochim. Cosmochim. Acta 2016, 179, 32-52. [CrossRef]

59. Hu, X.D.; Zhao, J.N.; Li, S.B. Gold Mineralization in Archean Metamorphic Rocks, Zhangjiakou-Xuanhua Area, Hebei Province; Geological Publishing House: Beijing, China, 1990. (In Chinese)

60. Johnson, J.W.; Oelkers, E.H.; Helgeson, H.C. SUPCRT92: A software package for calculating the standard molal thermodynamic properties of minerals, gases, aqueous species, and reactions from 1 to 5000 bar and 0 to $1000{ }^{\circ} \mathrm{C}$. Comput. Geosci. 1992, 18, 899-947. [CrossRef]

61. Zimmer, K.; Zhang, Y.; Lu, P.; Chen, Y.; Zhang, G.; Dalkilic, M.; Zhu, C. SUPCRTBL: A revised and extended thermodynamic dataset and software package of SUPCRT92. Comput. Geosci. 2016, 90, 97-111. [CrossRef]

62. Sverjensky, D.A.; Shock, E.L.; Helgeson, H.C. Prediction of the thermodynamic properties of aqueous metal complexes to 1000 degrees C and $5 \mathrm{~kb}$. Geochim. Cosmochim. Acta 1997, 61, 1359-1412. [CrossRef]

63. Mei, Y.; Sherman, D.M.; Liu, W.; Etschmann, B.; Testemale, D.; Brugger, J. Zinc complexation in chloride-rich hydrothermal fluids $\left(25-600^{\circ} \mathrm{C}\right)$ : A thermodynamic model derived from ab initio molecular dynamics. Geochim. Cosmochim. Acta 2015, 150, 265-284. [CrossRef]

64. Reed, M.H. Sulfide mineral precipitation from hydrothermal fluids. Rev. Miner. Geochem. 2006, 61, 609-631. [CrossRef]

65. Velasquez, G.; Carrizo, D.; Salvi, S.; Vela, I.; Pablo, M.; Pérez, A. Tracking Cobalt, REE and Gold from a porphyry-type deposit by LA-ICP-MS: A geological approach towards metal-selective mining in tailings. Minerals 2020, 10, 109. [CrossRef]

66. Zhai, D.; Williams-Jones, A.E.; Liu, J.; Tombros, S.F.; Ciobanu, C.L. Mineralogical, fluid inclusion, and multiple isotope (H-O-S-Pb) constraints on the genesis of the sandaowanzi epithermal Au-Ag-Te deposit, NE China. Econ. Geol. 2018, 113, 1359-1382. [CrossRef]

67. Bao, Z.; Li, C.; Zhao, Z. Metallogeny of the syenite-related Dongping gold deposit in the northern part of the North China Craton: A review and synthesis. Ore Geol. Rev. 2016, 73, 198-210. [CrossRef]

68. Gao, S.; Xu, H.; Zhang, D.; Shao, H.; Quan, S. Ore petrography and chemistry of the tellurides from the Dongping gold deposit, Hebei Province, China. Ore Geol. Rev. 2015, 64, 23-34. [CrossRef]

69. Yin, J.Z.; Zhai, Y.S. On the metallogenic seroes of gold deposits in Zhangjiakou-Xuanhua region, Hebei. J. Guilin Coll. Geol. 1994, 14, 360-369, (In Chinese with English abstract).

Publisher's Note: MDPI stays neutral with regard to jurisdictional claims in published maps and institutional affiliations. 